\title{
Behavior of Battery Metals Lithium, Cobalt, Manganese and Lanthanum in Black Copper Smelting
}

\author{
Anna Dańczak ${ }^{1, *}{ }^{\circledR}$, Lassi Klemettinen ${ }^{1} \oplus$, Matti Kurhila ${ }^{2} @$, Pekka Taskinen ${ }^{1}{ }^{\circledR}$, \\ Daniel Lindberg ${ }^{1}$ and Ari Jokilaakso ${ }^{1}$ (D)
}

1 School of Chemical Engineering, Department of Chemical and Metallurgical Engineering, Aalto University, P.O. Box 16100, Kemistintie 1, 02150 Espoo, Finland; lassi.klemettinen@aalto.fi (L.K.); pekka.taskinen@aalto.fi (P.T.); daniel.k.lindberg@aalto.fi (D.L.); ari.jokilaakso@aalto.fi (A.J.)

2 Geological Survey of Finland, Vuorimiehentie 2, 02150 Espoo, Finland; matti.kurhila@gtk.fi

* Correspondence: anna.danczak@aalto.fi; Tel.: +358-50-475-8677

Received: 31 January 2020; Accepted: 27 February 2020; Published: 2 March 2020

\begin{abstract}
Recycling of metals from different waste streams must be increased in the near future for securing the availability of metals that are critical for high-tech applications, such as batteries for e-mobility. Black copper smelting is a flexible recycling route for many different types of scrap, including Waste Electrical and Electronic Equipment (WEEE) and some end-of-life energy storage materials. Fundamental thermodynamic data about the behavior of battery metals and the effect of slag additives is required for providing data necessary for process development, control, and optimization. The goal of our study is to investigate the suitability of black copper smelting process for recycling of battery metals lithium, cobalt, manganese, and lanthanum. The experiments were performed alumina crucibles at $1300^{\circ} \mathrm{C}$, in oxygen partial pressure range of $10^{-11}-10^{-8} \mathrm{~atm}$. The slags studied contained 0 to $6 \mathrm{wt} \%$ of $\mathrm{MgO}$. Electron probe microanalysis (EPMA) and laser ablation-inductively coupled plasma-mass spectrometry (LA-ICP-MS) techniques were utilized for phase composition quantifications. The results reveal that most cobalt can be recovered into the copper alloy in extremely reducing process conditions, whereas lithium, manganese, and lanthanum deport predominantly in the slag at all investigated oxygen partial pressures.
\end{abstract}

Keywords: recycling; circular economy; pyrometallurgy; LA-ICP-MS

\section{Introduction}

\subsection{Context}

Nowadays, the importance of advanced rechargeable batteries is constantly growing because of their multiple applications, such as electric and hybrid vehicles, electronic communication devices, and numerous of energy storages used for stationary devices [1]. The demand for rechargeable batteries will increase with the growth of electric transportation and renewable energy. Business Finland predicts [2] that the need for batteries will increase more than ten-fold globally from 2015 to 2020. They also estimate that the combined value of the battery market in Europe will reach $€ 250$ billion by 2025 .

When applying lithium-ion batteries (LiBs) in electric and hybrid vehicles, long-term stability is required [3]. In recent years, great efforts have been made in order to develop new battery electrochemistries and optimize design variables for increasing cell performance and reducing degradation. Different models as tools for battery design and optimization have been elaborated in the literature [3-5].

End-of-life batteries will be a significant source of several metals, commonly present in higher concentrations than in their respective natural ores [6]. Nickel-metal-hydride (Ni-MH) and lithium-ion 
batteries (LiBs) contain such metals as $\mathrm{Co}, \mathrm{Cu}, \mathrm{Fe}, \mathrm{Li}, \mathrm{Mn}, \mathrm{Ni}, \mathrm{Pb}, \mathrm{V}[7,8]$, and rare earth elements (REE, mostly La, Ce, Sm, Nd, and Pr) [8]. Sverdrup et al. [9] estimated that different scrap metals will become a major source of $\mathrm{Fe}, \mathrm{Al}$, and $\mathrm{Cu}$ in the next 30 years. Among the main elements used in batteries, cobalt is considered as element with the highest supply risk. The increasing need for rechargeable batteries has resulted in an increase in cobalt consumption during the last decades. The global cobalt production reached 140,000 tons in 2018, whereas the estimated global reserves of cobalt are only 6.9 million tons [10]. Because of the growth in demand, limited resources, and price instability, the cobalt market is expected to be characterized by high fluctuations in the near future.

Currently, lithium is one of the most technologically valuable battery metals because of its unique properties [11]. In comparison to cobalt, lithium resource scarcity is not as strict; the global lithium reserves were estimated as 14 million tons in 2018 [12]. However, lithium resources are limited by geopolitical reasons $[1,13]$. Both the price and production of lithium have been increasing at a rapid rate [1]. Currently, the share of recycled lithium is less than 1\% [14]. Because of the lack of recycling technologies [15], lithium can be considered as a critical raw material (CRM) in the future.

Integrated batteries, which can be found for example in EoL laptops and mobile phones, also often end up in Waste Electrical and Electronic Equipment (WEEE) recycling [16]. Because of the advancements of technology, electronic waste may contain up to 50 elements, including precious metals (PMs) and hazardous metals [17]. Therefore, elemental composition of WEEE is becoming more demanding for the subsequent recycling processes. Developing and designing optimal smelting processes utilizing e-waste is one of the biggest challenges for the modern metal industry [16].

The metallurgical processing of spent batteries may be based on three different ways: pyrometallurgy, hydrometallurgy, or hybrid processes. The latter uses methods from pyro- and hydrometallurgy to produce metals or metal precursors $[6,18,19]$.

A typical pyrometallurgical process for battery material recycling involves burning of organic materials in high temperatures, followed by smelting of metals/oxides and finally metal reduction or recovery in the form of alloys [20]. Pyrometallurgical techniques just for LiBs and Ni-MH batteries, described in different review papers $[1,18]$, have been developed successfully and most of the elements are recovered [21]. However, the currently available processes are characterized by the loss of Li during the recycling, which is a significant problem that needs to be addressed [20]. Additionally, battery scrap is also extensively used as a locally available, secondary raw material for primary smelters/refineries. In those processes, the main goal is to recover only the base metal or metals, whereas the residual materials are impurities diluting to the slag phase [22].

Secondary copper processing, i.e., black copper smelting, is characterized by the presence of numerous trace elements at concentrations that may affect the thermodynamic behavior of other elements [16]. Moreover, copper smelter and converter slags usually contain about 1 to 10 pct of CaO, $\mathrm{Al}_{2} \mathrm{O}_{3}$ and $\mathrm{MgO}$, intentionally or otherwise [23]. Therefore, fundamental thermodynamic data about the distribution behavior of battery metals and the effect of slag additives must be obtained in order to provide data for process development, evaluation, and optimization. Currently, limited data is available considering the distributions of the elements present in batteries between the different phases in black copper smelting.

\subsection{Literature}

Takeda et al. [24] investigated the distributions of various metals between liquid copper and calcium ferrite slag $\left(\mathrm{FeO}_{\mathrm{x}}-\mathrm{CaO}\right)$ at $1250{ }^{\circ} \mathrm{C}$ in a wide range of oxygen partial pressures. Based on their results, the distribution coefficient of cobalt ( $w \mathrm{t} \%$ Co in metal/wt $\%$ Co in slag) decreased with increasing oxygen partial pressure $\mathrm{p}\left(\mathrm{O}_{2}\right)=10^{-10}$ to $10^{-6}$ atm from 1 to 0.005 and the suggested form of cobalt in slag was $\mathrm{CoO}$. Liu and Grimsey [25] studied the effects of $\mathrm{CaO}, \mathrm{Al}_{2} \mathrm{O}_{3}$, and $\mathrm{MgO}$ in iron silicate slag $\left(\mathrm{FeO}_{\mathrm{x}}-\mathrm{SiO}_{2}\right)$ on the activity coefficient of cobalt oxide, and found that it increased with the increasing contents of $\mathrm{CaO}, \mathrm{Al}_{2} \mathrm{O}_{3}$, and $\mathrm{MgO}$ in the slag. 
The behavior of manganese in $\mathrm{CaO}-\mathrm{SiO}_{2}-\mathrm{FeO}-\mathrm{MgO}-\mathrm{MnO}$ slag-molten iron system at oxygen partial pressure $2.7 \times 10^{-12}$ atm was investigated by Jung et al. [26]. The results showed that the equilibrium distribution coefficient of Mn between slag and iron increases with increasing FeO concentration and decreases with increasing basicity.

The thermodynamic behavior of $\mathrm{MnO}$ in the $\mathrm{CaO}-\mathrm{SiO}_{2}-\mathrm{MnO}$ slags at $1500{ }^{\circ} \mathrm{C}$ and oxygen partial pressure of $2.75 \times 10^{-10}$ atm was studied by Eom et al. [27]. Experimental results showed that manganese recovery can be increased by increasing the activity coefficient of $\mathrm{MnO}$ in the slag. The activity coefficient of $\mathrm{MnO}$ increased with increasing basicity and $\mathrm{MgO}$ concentration of the slag.

The phase equilibria in the $\mathrm{Al}_{2} \mathrm{O}_{3}-\mathrm{CaO}-\mathrm{Li}_{2} \mathrm{O}-{ }^{\prime \prime} \mathrm{MnO}^{\prime}-\mathrm{SiO}_{2}$ system, representing the most common components of LiBs recycling slag, in equilibrium with metallic alloy have been investigated by Haccuria et al. $[28,29]$. They determined the phase relations, liquidus surfaces and primary phase fields in the investigated system. A composite diagram of $\mathrm{MnO}-\mathrm{Al}_{2} \mathrm{O}_{3}-\mathrm{SiO}_{2}$ has been constructed taking into account the established data.

Guoxing et al. [30] elaborated a new smelting reduction method for spent LiBs, based on $\mathrm{MnO}-\mathrm{SiO}_{2}-\mathrm{Al}_{2} \mathrm{O}_{3}$ slag system. In the investigated system, $\mathrm{MnO}_{2}$ was used as the main slag former. After smelting at $1475^{\circ} \mathrm{C}, \mathrm{Co}, \mathrm{Ni}$, and $\mathrm{Cu}$ deported into metal alloy, while $\mathrm{Mn}$ and Li were diluted in the slag. The recovery of cobalt increased until $\mathrm{CaO}$ addition reached $2.0 \mathrm{wt} \%(\mathrm{w} / \mathrm{w})$, where $99.85 \%$ of $\mathrm{Co}$ was recovered. Further increase in $\mathrm{CaO}$ addition presented no benefits to Co recovery. Mn recovery into the metal alloy increased from $2.1 \mathrm{wt} \%$ to $11.3 \mathrm{wt} \%$ with increasing $\mathrm{CaO}$ addition (from $0 \mathrm{wt} \%$ to $8.0 \mathrm{wt} \%$ ), which was attributed to the increase of activity of $\mathrm{MnO}$ in the slag. The obtained $\mathrm{Mn}$ and Li-containing slag was subjected to hydrometallurgical treatment.

Tirronen et al. [22] studied the behavior of selected battery elements in copper converting conditions. According to them, Li, Co, and Mn deportments to copper alloy and copper sulphide matte were negligible and the elements ended up predominantly in the slag or solid magnetite. It is worth mentioning that in the study of Tirronen et al. [22], lithium concentrations were measured only in the slag and magnetite spinel.

The distribution equilibria of various trace elements between metallic copper alloy and silica-saturated $\mathrm{FeO}_{\mathrm{x}}-\mathrm{SiO}_{2}$ slags were investigated by Sukhomlinov et al. [31]. Equilibrium concentration of cobalt in the alloy was found to decrease with increasing oxygen partial pressure and with decreasing temperature. The suggested oxide form of cobalt dissolving in slag was CoO.

The behavior of rare earth elements (REEs) in black copper smelting conditions have not been investigated previously. Rare earth oxides (REOs) are characterized by high thermodynamic stability [32]; therefore, these elements end up in the slag during smelting [33]. Tirronen et al. [22] studied the behavior of neodymium in copper converting conditions whereas Klemettinen et al. [34] investigated the distribution kinetics of lanthanum and neodymium in copper flash smelting conditions. Both studies indicated that neodymium (as well as lanthanum) deportment to metallic copper and/or copper sulfide matte is negligible and this element ends up in the slag or magnetite phase.

According to previous studies, the distribution coefficient of cobalt between metal and slag increases in the presence of $\mathrm{CaO}, \mathrm{Al}_{2} \mathrm{O}_{3}$, and $\mathrm{MgO}$ in iron silicate slags. Naturally, the oxygen partial pressure also plays an important role in cobalt recovery. The distribution of manganese between metal alloy and slag phase also seems to be affected by the presence of different additives in the slag. There is no data on how those additives influence the behavior of lithium in different copper-slag systems. Moreover, manganese and lithium deportments in copper alloy appear to be negligible and those elements favor the slag phase under the conditions applied in the previous investigations.

The aim of this study is to provide accurate thermodynamic data of the battery element distributions between different phases in reducing copper scrap smelting conditions. This paper focuses on the distribution behaviors of $\mathrm{Li}, \mathrm{Co}, \mathrm{Mn}$, and $\mathrm{La}$, and provides fundamental data for process development, control, and optimization. Furthermore, in this study, the influence of $\mathrm{MgO}$ content in the slag on the trace element distributions was investigated. The experimental temperature was chosen as 1300 ${ }^{\circ} \mathrm{C}$, and the experiments were performed in reducing conditions between $10^{-11}$ and $10^{-8}$ atm oxygen 
partial pressures. The results will aid in selecting and developing the most suitable processes for battery recycling.

\section{Materials and Methods}

\subsection{Materials}

The slag and copper alloy mixtures were prepared from pure powders (Table 1). Trace elements $\mathrm{Ni}, \mathrm{Co}$, and $\mathrm{Sn}$ were introduced into the system as pure metals, whereas $\mathrm{La}, \mathrm{Mn}$, and $\mathrm{Li}$ were added in the form of $\mathrm{La}_{2} \mathrm{O}_{3}, \mathrm{MnO}$, and $\mathrm{Li}_{2} \mathrm{CO}_{3}$, respectively. The copper alloy was mixed of copper with $2 \mathrm{wt} \%$ of $\mathrm{Ni}, 1 \mathrm{wt} \%$ of $\mathrm{Co}$ and $5 \mathrm{wt} \%$ of $\mathrm{Sn}$. The slag was mixed of $\mathrm{Al}_{2} \mathrm{O}_{3}, \mathrm{SiO}_{2}$, and $\mathrm{Fe}_{2} \mathrm{O}_{3}$ with an initial $\mathrm{Fe} / \mathrm{SiO}_{2}$ ratio of 1.3. Three slag mixtures, with 0,3 , and $6 \mathrm{wt} \%$ of $\mathrm{MgO}$, were prepared for investigating the effect of magnesium oxide on the equilibrium. All starting slag mixtures contained $15 \mathrm{wt} \%$ of $\mathrm{Al}_{2} \mathrm{O}_{3}$ and $1 \mathrm{wt} \%$ of $\mathrm{La}, \mathrm{Mn}$ and $\mathrm{Li}$ each. This article focuses on the behavior of $\mathrm{Li}, \mathrm{Co}, \mathrm{Mn}$, and $\mathrm{La}$.

Table 1. The materials utilized for preparing copper alloy and slag mixtures.

\begin{tabular}{|c|c|c|c|}
\hline Chemical & $\begin{array}{l}\text { Purity } \\
\text { (wt\%) }\end{array}$ & Form & Supplier \\
\hline $\mathrm{Cu}$ & $99.9 \%$ & powder & Alfa Aesar, Kandel, Germany \\
\hline Co & $99.99 \%$ & sponge & Koch-Light Laboratories Ltd, Colnbrook, UK \\
\hline $\mathrm{Ni}$ & $99.996 \%$ & powder, APS 3-7 micron & Alfa Aesar, Kandel, Germany \\
\hline Sn & $99.85 \%$ & powder, 100 mesh & Alfa Aesar, Kandel, Germany \\
\hline $\mathrm{La}_{2} \mathrm{O}_{3}$ & $99.9 \%$ & powder & Alfa Aesar, Kandel, Germany \\
\hline $\mathrm{MnO}$ & $99.99 \%$ & powder/chunks & Alfa Aesar, Kandel, Germany \\
\hline $\mathrm{Li}_{2} \mathrm{CO}_{3}$ & $99.998 \%$ & powder & Alfa Aesar, Kandel, Germany \\
\hline $\mathrm{MgO}$ & 99.95 & powder, 325 mesh & Alfa Aesar, Kandel, Germany \\
\hline $\mathrm{Al}_{2} \mathrm{O}_{3}$ & $99.99 \%$ & powder & Sigma Aldrich, St. Louis, MO, USA \\
\hline $\mathrm{SiO}_{2}$ & $99.995 \%$ & powder, 40 mesh & Alfa Aesar, Kandel, Germany \\
\hline $\mathrm{Fe}_{2} \mathrm{O}_{3}$ & $99.999 \%$ & powder & Alfa Aesar, Kandel, Germany \\
\hline
\end{tabular}

\subsection{Methods}

The experimental technique employed in this study was high-temperature equilibration of a sample at a controlled temperature and gas atmosphere, followed by rapid quenching into ice-water mixture. This method has been described in detail in previous publications $[31,35,36]$.

All experiments presented in this work were conducted in a vertical laboratory furnace (Nabertherm, Lilienthal, Germany, RHTV 120-150/18) equipped with $\mathrm{MoSi}_{2}$ heating elements, Nabertherm P310 temperature controller and an alumina reaction tube (Frialit AL 23; Friatec AG, Mannheim, Germany; $45 \mathrm{~mm}$ OD and $38 \mathrm{~mm}$ ID). The furnace and the sample temperatures were measured with a calibrated $\mathrm{Pt} / \mathrm{Pt} 10 \mathrm{Rh}$ thermocouple (Johnson-Matthey, London, UK) with an uncertainty of $\pm 3^{\circ} \mathrm{C}$. Schematic of the equilibrium furnace, its gas train, and the sample position inside the furnace have been presented in earlier studies [31,36,37].

For every experiment, approximately $200 \mathrm{mg}$ of copper alloy and $200 \mathrm{mg}$ of slag mixture were placed in a small alumina crucible (Frialit AL 23; Friatec AG, Mannheim, Germany). The sample setup inside the furnace work tube during the experiments has been presented schematically in an earlier study [35]. All experiments were duplicated for reliability.

The experiments were conducted for all slag compositions (with 0,3 , and $6 \mathrm{wt} \%$ of $\mathrm{MgO}$ ) at $1300{ }^{\circ} \mathrm{C}$ in the $\mathrm{pO}_{2}$ range from $10^{-11}$ to $10^{-8} \mathrm{~atm}$. The gas atmosphere in the furnace was mixed of $\mathrm{CO}$ (99.97\%, Linde-AGA, Espoo, Finland) and $\mathrm{CO}_{2}$ (99.9992 \%, Linde-AGA, Espoo, Finland), with a total flow rate of $300 \mathrm{ml} / \mathrm{min}$. The flow rates of gases were regulated at room temperature $\left(\sim 20^{\circ} \mathrm{C}\right)$, as the mass flow controllers were in room temperature. The prevailing oxygen partial pressures were calculated at the experimental temperature $\left(1300^{\circ} \mathrm{C}\right)$ using MTDATA software and the SGTE pure substances database [38]. The calculated partial pressures and flow rates utilized in the experiments 
are presented in Table 2. After quenching, the samples were cut in half and mounted in epoxy resin. Traditional metallographic methods of dry grinding and polishing were employed for preparation of sample cross sections.

Table 2. The calculated oxygen partial pressures and used gas flow rates $\left(\mathrm{T}=1300{ }^{\circ} \mathrm{C}, \mathrm{P}_{\text {tot }}=1 \mathrm{~atm}\right)$.

\begin{tabular}{cccc}
\hline $\begin{array}{c}\log _{10} \\
\mathbf{p}\left(\mathbf{O}_{2}\right) / \mathbf{a t m}\end{array}$ & $\begin{array}{c}v \mathrm{CO}_{2} \\
(\mathbf{m L} / \mathbf{m i n})\end{array}$ & $\begin{array}{c}v \mathrm{CO} \\
(\mathbf{m L} / \mathbf{m i n})\end{array}$ & $\mathrm{CO}_{2} / \mathrm{CO}$ \\
\hline-11.0 & 56.0 & 244.0 & 0.23 \\
-10.0 & 125.6 & 174.5 & 0.72 \\
-9.0 & 208.5 & 91.5 & 2.28 \\
-8.0 & 263.4 & 36.6 & 7.20 \\
\hline
\end{tabular}

The required equilibrating time was determined by annealing samples of $200 \mathrm{mg}$ of $\mathrm{Fe}_{2} \mathrm{O}_{3}-\mathrm{SiO}_{2}-\mathrm{Al}_{2} \mathrm{O}_{3}(15 \mathrm{wt} \%)-\mathrm{MgO}(3 \mathrm{wt} \%)$ slag with an equal amount of $\mathrm{Cu}-\mathrm{Sn}(5 \mathrm{wt} \%)$ alloy in the alumina crucible at $1300{ }^{\circ} \mathrm{C}$ and at $10^{-10}$ atm oxygen partial pressure for $8,16,24$, and $48 \mathrm{~h}$. The equilibration time was defined according to the concentrations of $\mathrm{Fe}, \mathrm{Al}, \mathrm{Si}$, and $\mathrm{Mg}$ in the slag and spinel phases, and the concentrations of copper and tin in the metal phase. The homogeneity of all samples was examined by Tescan Mira3 SEM (Scanning Electron Microscope, Tescan, Brno, Czech Republic) and the elemental compositions from time series experiments were determined with an UltraDry Silicon Drift EDS (Energy Dispersive Spectrometer, Thermo Fisher Scientific, Waltham, MA, USA). An acceleration voltage of $15 \mathrm{kV}$ was used, and the quantifications were made using Proza ZAF correction [39]. Based on the results, the minimum required equilibrium time was found to be $16 \mathrm{~h}$; however, to ensure the equilibrium at all oxygen pressures, the annealing time was set to $24 \mathrm{~h}$ for every experiment.

The accurate phase (copper alloy, liquid slag, solid spinel) compositions with a special emphasis on trace element concentrations were analyzed using electron probe microanalysis (SX-100 EPMA, Cameca SAS, Gennevilliers, France), housed at Geological Survey of Finland (GTK). The number of measurements in metal and slag phases was eight in minimum, whereas in spinel it was six. The beam diameter was $100 \mu \mathrm{m}$ for the metal phase, 50-100 $\mu \mathrm{m}$ for slag phase (depending on the available homogeneous slag areas), and $1 \mu \mathrm{m}$ for the spinel phase. An accelerating voltage of $20 \mathrm{kV}$ and a beam current of $60 \mathrm{nA}$ were employed. For the major elements, the counting times were set to $10 \mathrm{~s}$ for the peak and $5 \mathrm{~s}$ for the background on both sides of the peak. For trace elements, the respective times were $60 \mathrm{~s}$ and $30 \mathrm{~s}$. The primary EPMA WDS data were treated with PAP matrix correction software [40]. The standards and analyzed X-ray lines in EPMA analyses were as follows: quartz (Si K $\alpha$ ), almandine $(\mathrm{Al} \mathrm{K} \alpha)$, diopside $(\mathrm{Mg} \mathrm{K} \alpha)$, hematite $(\mathrm{Fe} \mathrm{K} \alpha$ and $\mathrm{O} \mathrm{K} \alpha)$, pentlandite $(\mathrm{Ni} \mathrm{K} \alpha)$, lanthanum phosphate $(\mathrm{La} \mathrm{L} \alpha)$, synthetic pure copper $(\mathrm{Cu} \mathrm{K} \alpha)$, cobaltite $(\mathrm{Co} \mathrm{K} \alpha)$, and tin ( $\mathrm{Sn} \mathrm{L} \alpha)$. The detection limits of EPMA measuring campaign are presented in Table 3.

The manganese and lanthanum concentrations were below the detection limits of EPMA in the copper alloy, and lithium cannot be analyzed with EPMA, as it is too light an element. Therefore, the samples were also analyzed with laser ablation-inductively coupled plasma-mass spectrometer (LA-ICP-MS) at GTK. The equipment was an AttoM single collector ICP-MS system (Nu Instruments Ltd., Wrexham, UK) coupled with a Photon Machines $193 \mathrm{~nm}$ ArF excimer laser ablation device (Teledyne CETAC Technologies, Omaha, NE, USA). The metal phase was analyzed with $50 \mu$ m diameter spots, a laser pulse frequency of $10 \mathrm{~Hz}$, a power of $3.2 \mathrm{~J} / \mathrm{cm}^{2}$, and He-Ar carrier gas. UQAC FeS-1 pressed sulphide pellet [41] was used for calibration and USGS MASS1 (U.S. Geological Survey, Denver, CO, USA) [42] as a monitor. The slag phase was analyzed with $65 \mu \mathrm{m}$ spots and a power of $2.5 \mathrm{~J} / \mathrm{cm}^{2}$. NIST 610 and NIST 612 reference materials [43] were used for calibration and as a monitor, respectively.

In all analyses, five pre-ablation pulses were fired to remove the carbon coating and other contamination from the sample surface, followed by $20 \mathrm{~s}$ of flushing, $20 \mathrm{~s}$ of gas background collection, and $40 \mathrm{~s}$ of data acquisition. ${ }^{61} \mathrm{Ni}$ (copper alloy) or ${ }^{29} \mathrm{Si}$ (slag) were used as internal standards. The 
detection limits of LA-ICP-MS have been collected in Table 3. The primary results are shown in Appendix A, Tables A1 and A2. In some cases, the concentrations were even below the detection limits of the ICP-MS; these have been indicated in Table A2.

Table 3. The elemental/isotopic detection limits of electron probe microanalysis (EPMA) and laser ablation-inductively coupled plasma-mass spectrometry (LA-ICP-MS) for each phase analyzed. (ppmw = parts per million by weight.).

\begin{tabular}{|c|c|c|c|c|c|c|c|c|c|c|c|}
\hline \multicolumn{12}{|c|}{ EPMA Detection Limit (ppmw) } \\
\hline Phase & $\mathbf{O}$ & $\mathrm{Si}$ & Al & Mg & $\mathrm{Fe}$ & $\mathbf{N i}$ & $\mathrm{Cu}$ & Co & Mn & La & Sn \\
\hline Cu-alloy & 451 & 149 & 133 & 175 & 77 & 268 & 348 & 80 & 84 & 247 & 153 \\
\hline Slag & 1088 & 203 & 203 & 91 & 199 & 94 & 278 & 105 & 196 & 278 & 146 \\
\hline Spinel & 1082 & 81 & 216 & 91 & 204 & 111 & 113 & 118 & 194 & 199 & 145 \\
\hline \multicolumn{12}{|c|}{ LA-ICP-MS Detection Limit (ppmw) } \\
\hline Phase & \multicolumn{2}{|c|}{ Si } & $\mathbf{N i}$ & \multicolumn{2}{|c|}{ Co } & \multicolumn{2}{|c|}{ Mn } & \multicolumn{2}{|c|}{$\mathbf{L i}$} & \multicolumn{2}{|c|}{ La } \\
\hline Cu-alloy & \multirow{2}{*}{\multicolumn{2}{|c|}{$\begin{array}{l}{ }^{29} \mathrm{Si}: 54.0 \\
29\end{array}$}} & ${ }^{61} \mathrm{Ni}: 4.05^{1}$ & \multicolumn{2}{|c|}{${ }^{59} \mathrm{Co}: 0.07$} & \multicolumn{2}{|c|}{${ }^{55} \mathrm{Mn}: 0.35$} & \multicolumn{2}{|l|}{${ }^{7} \mathrm{Li}: 0.81$} & \multicolumn{2}{|c|}{${ }^{139} \mathrm{La} 0.01$} \\
\hline Slag & & & ${ }^{61} \mathrm{Ni}: 0.57$ & \multicolumn{2}{|c|}{${ }^{59} \mathrm{Co}: 0.01$} & \multicolumn{2}{|c|}{${ }^{55} \mathrm{Mn}: 0.03$} & \multicolumn{2}{|l|}{${ }^{7} \mathrm{Li}: 0.12$} & \multicolumn{2}{|c|}{${ }^{139} \mathrm{La}: 0.001$} \\
\hline
\end{tabular}

\section{Results and Discussion}

\subsection{Equilibrium Sample Microstructure and Slag Composition}

Figure 1 shows a typical sample microstructure and the equilibrium phases $\left(\mathrm{T}=1300{ }^{\circ} \mathrm{C}, \mathrm{p}\left(\mathrm{O}_{2}\right)=\right.$ $10^{-8} \mathrm{~atm}, 6 \mathrm{wt} \%$ of $\mathrm{MgO}$ in initial slag mixture). All samples comprised of metal alloy, glassy slag phase, spinel (layer and individual grains), and the alumina crucible. All phases after rapid quenching were homogeneous, except the copper alloy, where segregations containing higher concentrations of tin were observed.

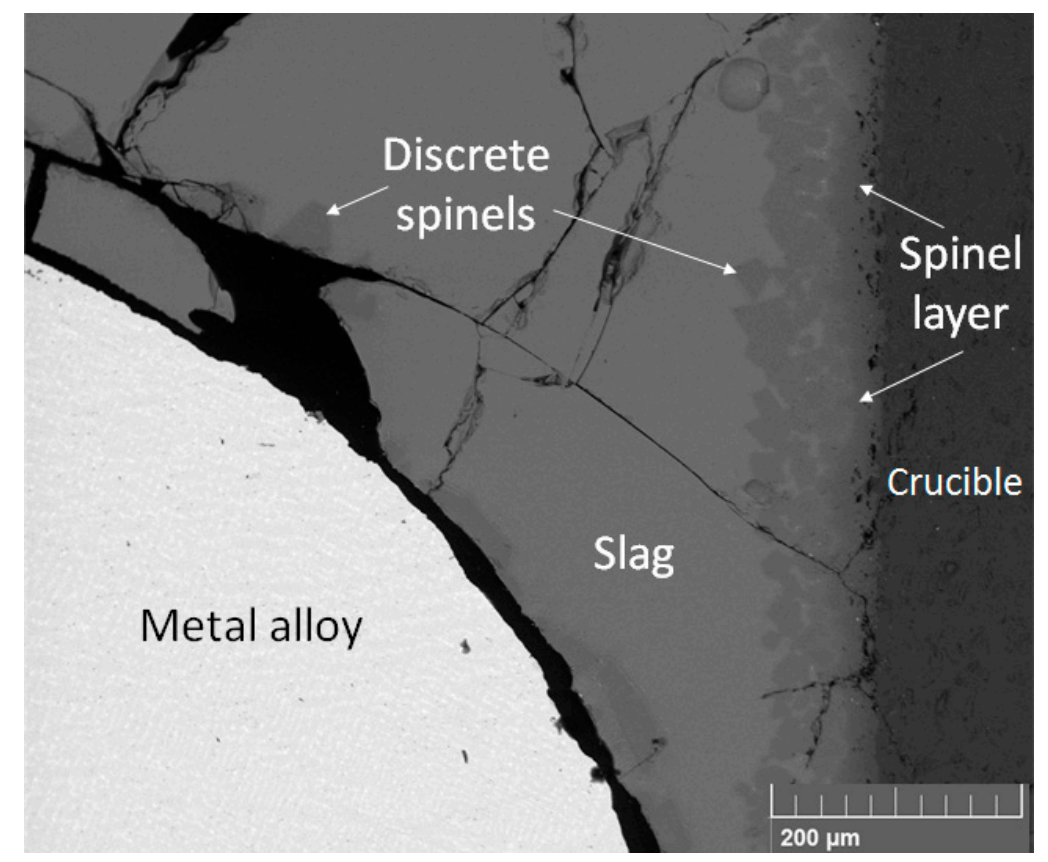

Figure 1. A typical sample microstructure $\left(\mathrm{p}\left(\mathrm{O}_{2}\right)=10^{-8} \mathrm{~atm}, 6 \mathrm{wt} \%\right.$ of $\mathrm{MgO}$ in the slag mixture).

The initial slag contained 0, 3, or $6 \mathrm{wt} \% \mathrm{MgO}$. In equilibrium, about 2/3 of $\mathrm{MgO}$ distributed to the liquid slag and the rest deported to the spinel. Therefore, the equilibrium concentrations of $\mathrm{MgO}$ 
in the slag, in the MgO-containing systems, were approximately 2 and $4.5 \mathrm{wt} \%$, respectively. The equilibrium concentration of alumina in the slag was between 18 and $20 \mathrm{wt} \%$, which is in agreement with the results of Klemettinen et al. [36,37]. However, when $\mathrm{MgO}$-concentration in the slag increased, the $\mathrm{Al}_{2} \mathrm{O}_{3}$ concentration decreased correspondingly; with $4.5 \mathrm{wt} \% \mathrm{MgO}$ in slag, the concentration of $\mathrm{Al}_{2} \mathrm{O}_{3}$ was between 14 and $16 \mathrm{wt} \%$. Therefore, the changes in measured concentration values of trace metals $\mathrm{Li}, \mathrm{Co}, \mathrm{Mn}$, and $\mathrm{La}$ in different slag systems were actually functions of both increasing $\mathrm{MgO}$ and decreasing $\mathrm{Al}_{2} \mathrm{O}_{3}$ concentrations in the slag.

\subsection{Li, Co, Mn, and La Behavior in Copper-Slag-Spinel System}

Figure 2 shows the measured equilibrium concentrations of lithium, cobalt, manganese, and lanthanum in the copper alloy as a function of oxygen partial pressure. Lithium, manganese, and lanthanum concentrations were analyzed with LA-ICP-MS. For lithium and lanthanum, some of the measured concentration values were even below the detection limit of LA-ICP-MS; therefore, their concentrations presented in Figure 2A,D are the averages of those values, which were above the detection limit. At $\mathrm{p}\left(\mathrm{O}_{2}\right)=10^{-11}$ atm, lithium concentration in copper was below the detection limit in every spot analyzed from the $\mathrm{MgO}$-containing samples.
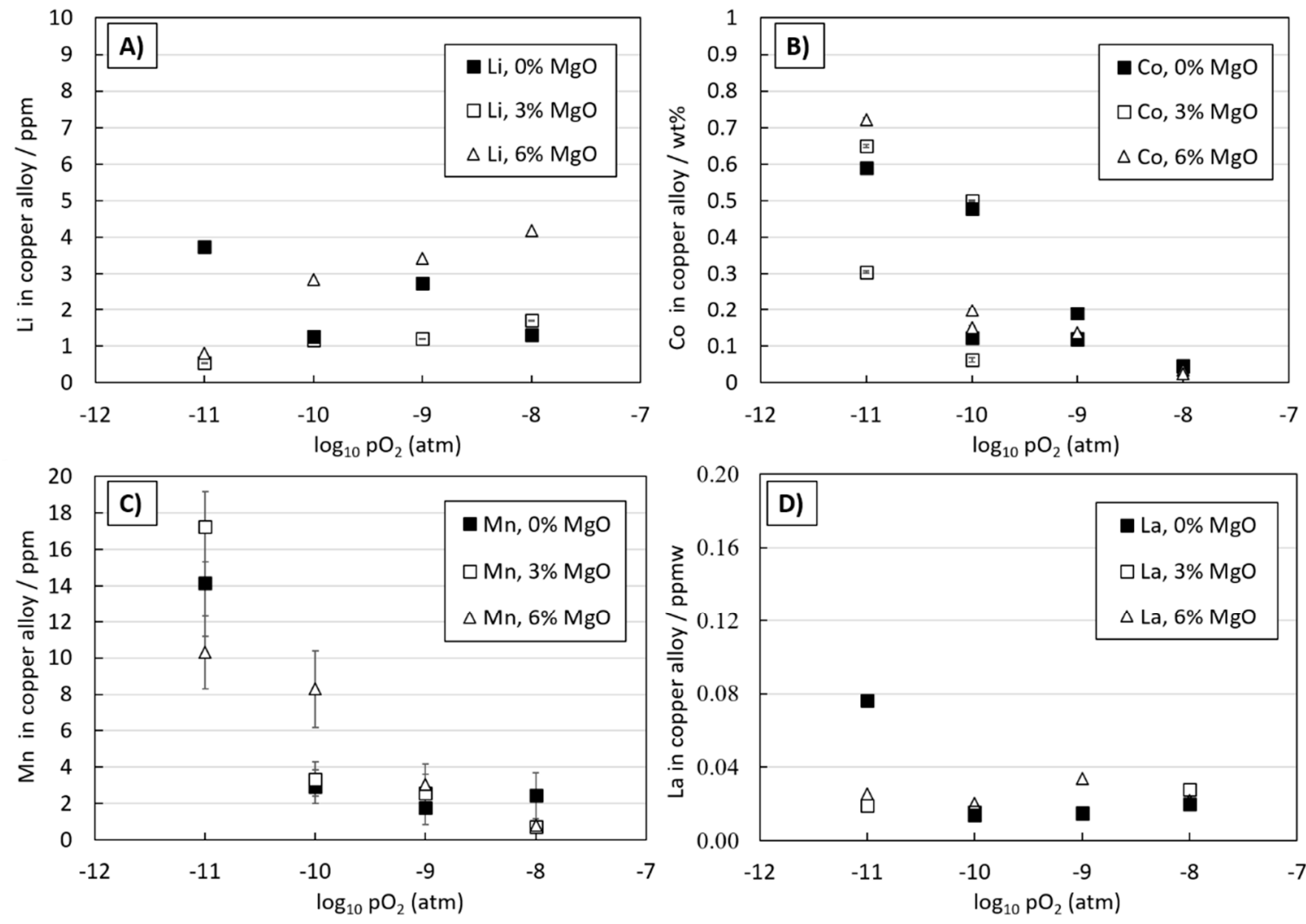

Figure 2. Trace elements (A) Li, (B) Co, (C), Mn, and (D) La concentrations in the copper alloy as a function of oxygen partial pressure at $1300^{\circ} \mathrm{C}$.

In equilibrium, lithium, manganese, and lanthanum exhibited extremely low concentrations in the alloy in all experiments. For lithium and lanthanum, the concentrations remained virtually constant between 1-4 ppm and 0.02-0.08 ppm respectively, as for manganese, it increased as a function of decreasing oxygen partial pressure.

The concentration of cobalt in copper alloy decreased steadily from approximately $0.65 \mathrm{wt} \%$ to 0.05 wt \% with increasing oxygen partial pressure. The concentration was lower in some samples because of the sticking of cobalt on the stainless steel spoon used for weighing the initial powders. 
The concentrations of lithium, cobalt, manganese, and lanthanum in the studied slags are shown in Figure 3. Lithium concentration in the slag was constant at every oxygen partial pressure (approximately $1 \mathrm{wt} \%$ ) and increased slightly (to 1.1-1.3 $\mathrm{wt} \%$ ) with the presence of $\mathrm{MgO}$ in the slag. Manganese and lanthanum exhibited similar behavior, their concentrations being between approximately 0.8 and $1.1 \mathrm{wt} \%$. For cobalt, a clear increase in the deportment to the slag phase was evident as the oxygen partial pressure increased.
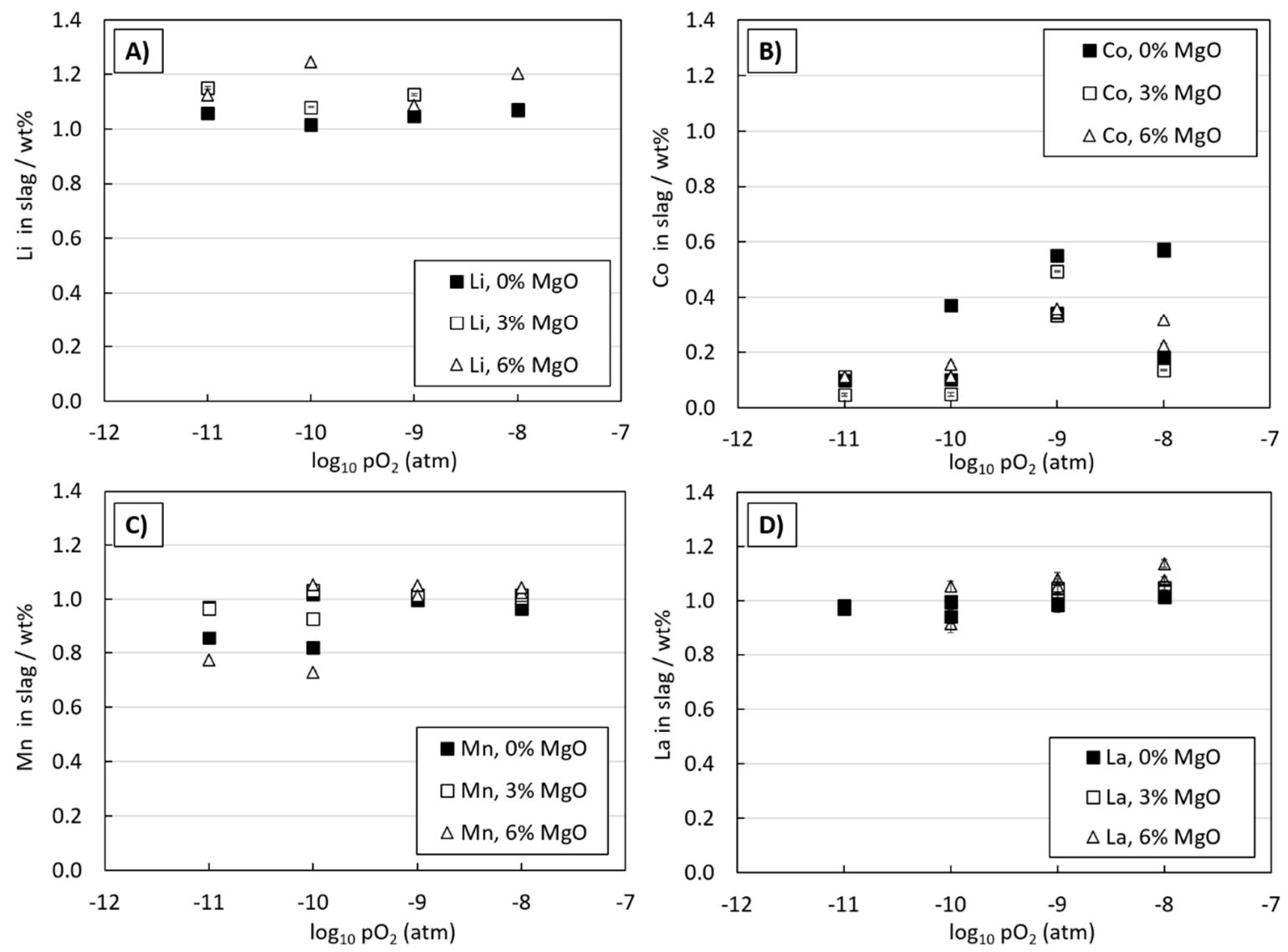

Figure 3. Trace element (A) Li, (B) Co, (C), Mn, and (D) La concentrations in the slags as a function of oxygen partial pressure at $1300{ }^{\circ} \mathrm{C}$.

Figure 4 presents the cobalt and manganese concentrations in iron-alumina spinel as a function of oxygen partial pressure. In our study, a dense spinel layer was formed between the slag and alumina crucible. In all samples, with and without $\mathrm{MgO}$ in the system, separate spinel crystals were also present floating within the slag. Avarmaa et al. [44] showed that the composition analyses from these discrete spinels in the slag can be considered as more accurate and representative of the equilibrium spinel composition. Therefore, $\mathrm{Mn}$ and $\mathrm{Co}$ concentrations were analyzed from the discrete spinel crystals. The $\mathrm{Li}$ and La concentrations were below the EPMA detection limits.

Without magnesia, the general formula of the spinel can be written as $\mathrm{Fe}(\mathrm{Al}, \mathrm{Fe})_{2} \mathrm{O}_{4}$. The addition of $\mathrm{MgO}$ had an effect on the spinel composition, as some of the divalent iron was replaced by magnesium, changing the general composition to $(\mathrm{Mg}, \mathrm{Fe})(\mathrm{Al}, \mathrm{Mg}, \mathrm{Fe})_{2} \mathrm{O}_{4}$.

The concentration of $\mathrm{MgO}$ in the equilibrium system seemed to have an influence on the solubility of manganese in the discrete spinels. The concentration of $\mathrm{Mn}$ increased slightly as the oxygen partial pressure increased, and the addition of $\mathrm{MgO}$ decreased the equilibrium solubility of manganese in the spinel. For cobalt, the solubility in the spinel increased with increasing oxygen partial pressure and was relatively high at $\mathrm{p}\left(\mathrm{O}_{2}\right)=10^{-8} \mathrm{~atm}$, even above $1.5 \mathrm{wt} \%$, which is higher than for copper. The addition of $\mathrm{MgO}$ seemed to have a slight decreasing effect on the cobalt concentration as well. 

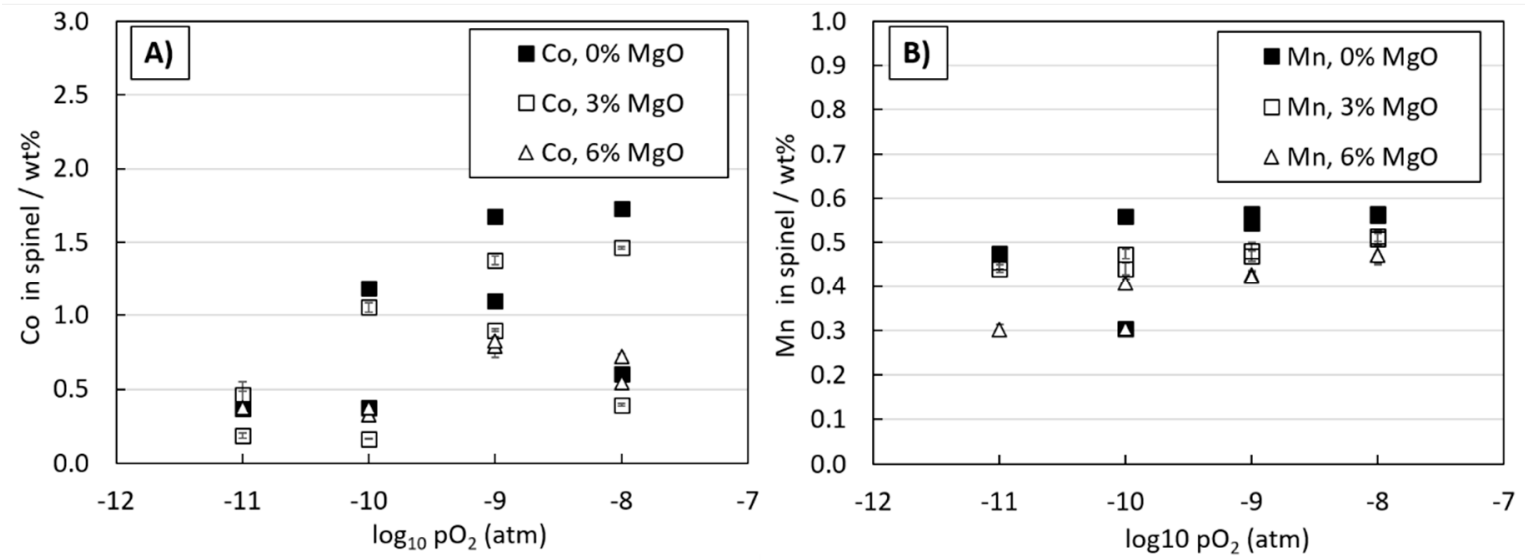

Figure 4. Concentrations of cobalt and manganese in spinel as a function of oxygen partial pressure at $1300{ }^{\circ} \mathrm{C}$.

\subsection{Distributions of Metals between Copper Alloy and Slag}

The theoretical background for the distribution equilibrium of a metal (Me) between two phases, and a definition for the distribution coefficient have been presented previously [25,31,35-37,44]. In this work, the distribution coefficient values shown in Figures 5-8 were calculated as $\mathrm{L}^{\mathrm{Cu} / \mathrm{s}} \mathrm{Me}=\mathrm{wt} \% \mathrm{Me}$ in alloy/wt $\%$ Me in slag. When the logarithm of the distribution coefficient $\mathrm{L}$ is plotted as a function of logarithm of oxygen partial pressure, the slope of a trend line fitted to the experimental points gives the oxidation degree of Me in slag, as depicted earlier [31,44].

The calculated distribution coefficients of lithium, lanthanum, and manganese between copper alloy and molten alumina-containing iron silicate slag as a function of oxygen partial pressure are presented in Figures 5-7, respectively. The obtained values are very low, as the LA-ICP-MS data from the copper alloy showed $\mathrm{Li}, \mathrm{La}$, and Mn concentrations less than 4 ppmw, 0.08 ppmw, and 18 ppmw, respectively, in the investigated oxygen partial pressure range. The very low distribution coefficients agree with the thermodynamic calculations, presented in Appendix B, Figure A1, which proposed that lithium, lanthanum, and manganese oxides are characterized by very high stability at $1300{ }^{\circ} \mathrm{C}$. It is worth noticing that the distribution coefficients of lithium and lanthanum between copper alloy and slags are upper estimates only, as their concentrations in copper alloy were below the detection limits of LA-ICP-MS in some analysis spots, i.e., the average values reported have been calculated from less than eight analyses per sample. In the case of $\mathrm{MgO}$-containing slags, the lithium concentrations were below detection limits in all analyses at $\mathrm{p}\left(\mathrm{O}_{2}\right) 10^{-11} \mathrm{~atm}$.

The distribution coefficients of lithium and lanthanum between metallic copper alloy and slag have not been reliably quantified previously. Tirronen et al. [22] provided data about the behavior of lithium and neodymium (which behaves very similarly as lanthanum [34]), and presented distribution coefficients between slag and the primary magnetite phase. However, they did not characterize the metallic phase with a technique capable of analyzing lithium at all and lanthanum reliably, therefore, not providing accurate numerical values for the distribution coefficients between copper and slag.

The distribution coefficient of manganese between copper alloy and slag, presented in Figure 7, decreased significantly with increasing oxygen partial pressure. The slope of the trend line for the distribution coefficient varied between -0.48 and -0.41 , depending on the composition of the slag. This indicates that manganese dissolves in the iron silicate slag as $\mathrm{MnO}$.

When comparing to earlier literature data [22,26,27], the calculated values of manganese distribution coefficient between copper alloy and slag appear to be much lower in this study. Jung et al. [26] studied the manganese distribution between $\mathrm{Cu}$ alloy and $\mathrm{CaO}-\mathrm{SiO}_{2}-\mathrm{Al}_{2} \mathrm{O}_{3}(13 \%)-$ $\mathrm{MnO}(5 \%)-\mathrm{MgO}(17 \%)$ slag at $1500^{\circ} \mathrm{C}$ and at oxygen partial pressure $2.71 \times 10^{-12} \mathrm{~atm}$. Eom et al. [27] investigated the manganese distribution between copper alloy and $\mathrm{CaO}-\mathrm{SiO}_{2}-\mathrm{Al}_{2} \mathrm{O}_{3}(14.7 \%)-\mathrm{MnO}(7.5 \%)$ slag at $1500^{\circ} \mathrm{C}$ and at oxygen partial pressure $2.75 \times 10^{-10} \mathrm{~atm}$. The distribution coefficients obtained 
in these studies have been plotted in Figure 7 for comparison. It should be noted that our experimental temperature was $200^{\circ} \mathrm{C}$ lower, and the earlier studies did not have iron oxide in the slag phase.

The experimental system used by Tirronen et al. [22] was closest to our system; however, the distribution coefficient values obtained for manganese and lanthanum were also considerably higher than our values (Figures 6 and 7). The differences between our study and that of Tirronen et al. [22] can be explained by the fact that in the their investigations, the values of manganese and lanthanum concentration in copper alloy, measured only by EPMA, were significantly below the detection limit of the instrument in all samples.

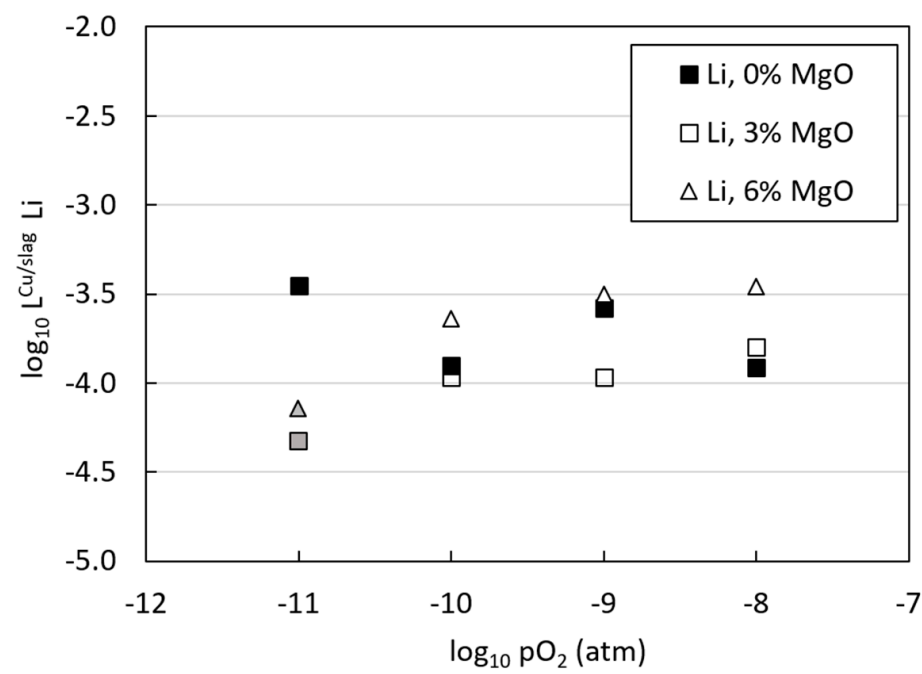

Figure 5. The distribution coefficient of lithium between copper alloy and molten slag. The values for MgO-containing slags in $\mathrm{p}\left(\mathrm{O}_{2}\right)=10^{-11}$ atm (grey triangle and square) have been calculated based on the detection limits in the copper alloy, as the concentrations were below detection limits of LA-ICP-MS in all analysis points.

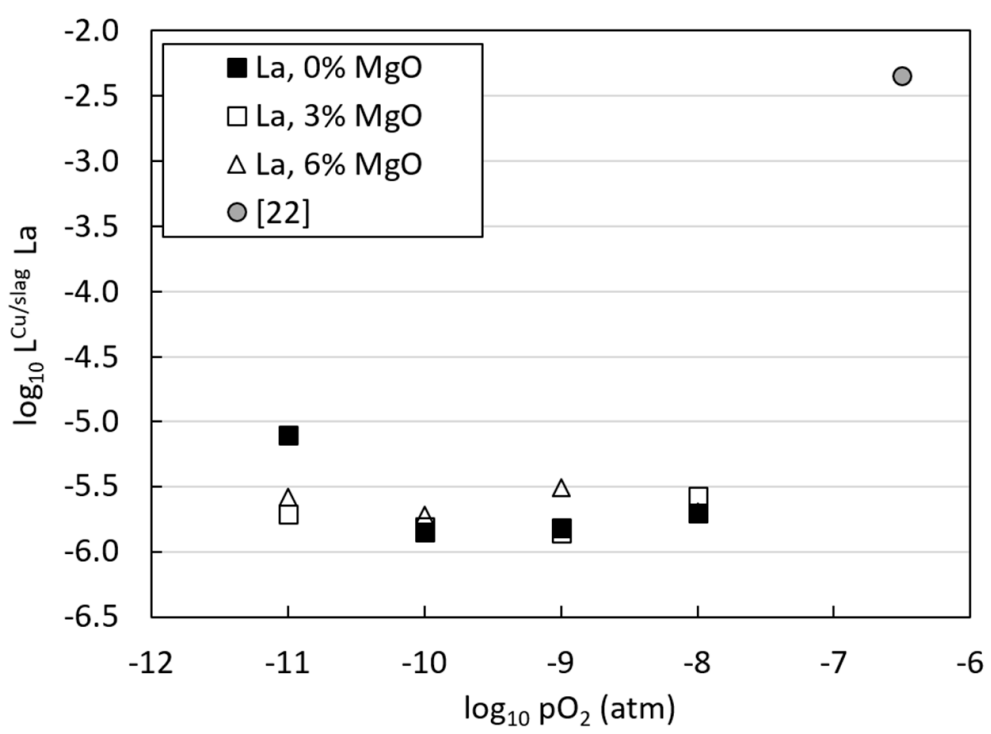

Figure 6. The distribution coefficient of lanthanum between copper alloy and molten slag. A result for neodymium (which behaves very similarly as lanthanum) from an earlier study [22] has been plotted for comparison. 


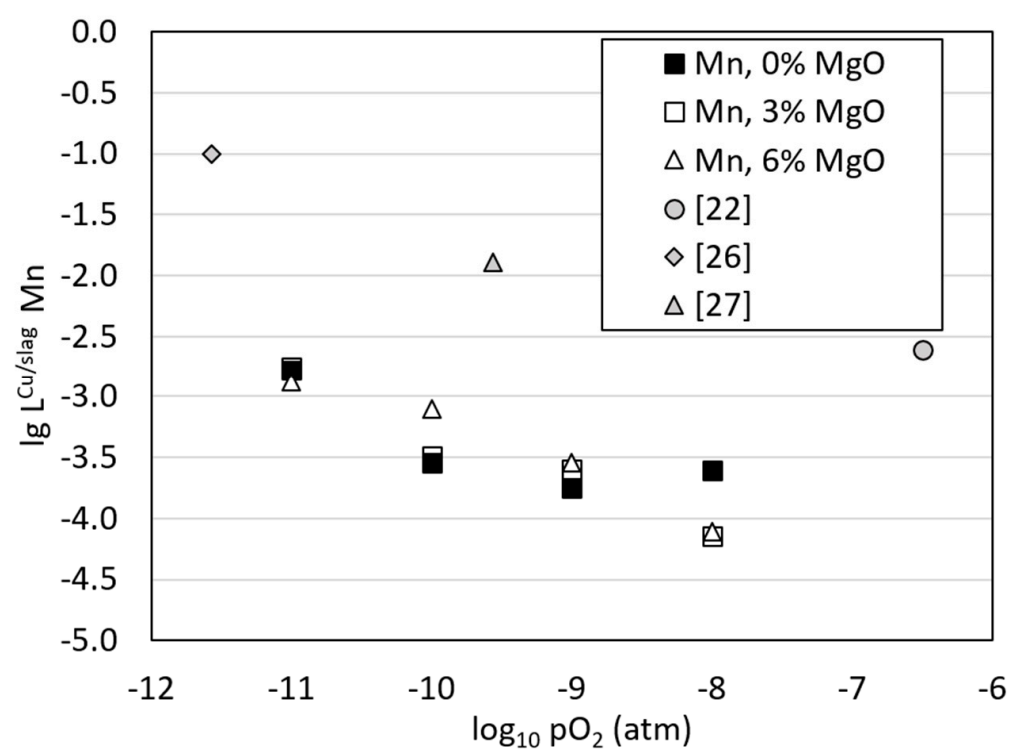

Figure 7. The distribution coefficient of manganese between copper alloy and slag as a function of oxygen partial pressure. Results from three earlier studies $[22,26,27]$ have been plotted for comparison.

Figure 8 shows the calculated distribution coefficients of cobalt between copper alloy and slag. In comparison to lithium, lanthanum, and manganese, the distribution coefficient of cobalt was much higher in all oxygen partial pressures. The distribution of cobalt favored the copper alloy at oxygen partial pressures below $10^{-10} \mathrm{~atm}$, whereas in more oxidizing conditions, $\mathrm{p}\left(\mathrm{O}_{2}\right)$ above $10^{-10} \mathrm{~atm}$, cobalt distribution preferred the molten slag phase.

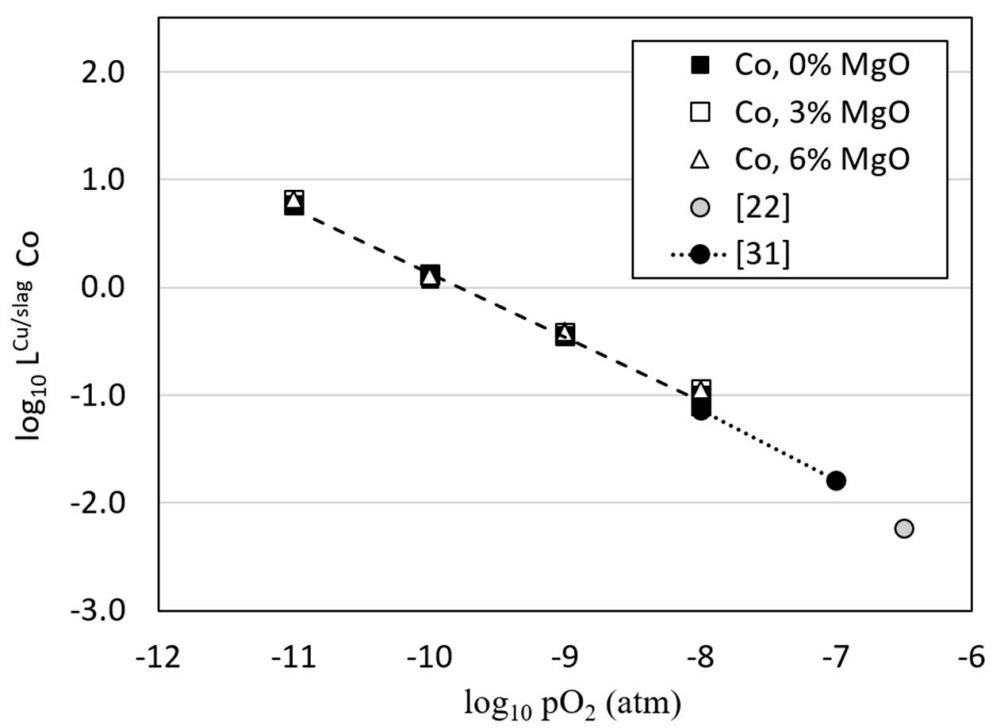

Figure 8. The distribution coefficient of cobalt between copper alloy and molten slag. Results from two earlier studies are plotted for comparison.

The slope of the trend line for the distribution coefficient of cobalt was approximately 0.6 , which corresponds well with the results of Sukhomlinov et al. [31] for pure, silica-saturated iron silicate slag $\left(\mathrm{FeO}_{\mathrm{x}}-\mathrm{SiO}_{2}\right)$ at $1300^{\circ} \mathrm{C}$ and $\mathrm{p}\left(\mathrm{O}_{2}\right)=10^{-8}-10^{-7} \mathrm{~atm}$, and of Tirronen et al. [22] for Cu-Fe-O-S-SiO 2 system at $1275^{\circ} \mathrm{C}$ and $\mathrm{p}\left(\mathrm{O}_{2}\right)=10^{-6.5} \mathrm{~atm}$. When comparing our results with the two aforementioned studies, the effect of the saturation phase appears to be very small.

Our results together with the results of Tirronen et al. [22] and Sukhomlinov et al. [31] do not seem to agree with the results of Liu and Grimsey [25]. They investigated the effects of $\mathrm{MgO}$ and 
$\mathrm{Al}_{2} \mathrm{O}_{3}$ additions to iron silicate slags on the activity coefficient of cobalt oxide, $\gamma_{\mathrm{CoO}}$, at oxygen partial pressure of $10^{-9}$ to $10^{-10}$ atm and $1200^{\circ} \mathrm{C}$. According to their findings, $\gamma_{\mathrm{CoO}}$ increases with increasing concentration of alumina and magnesia in the slag. An increase in the activity coefficient would cause an increase in the copper-slag distribution coefficient of cobalt between metal and slag. This effect was not visible in the results plotted in Figure 8. The discrepancy is likely because in our study, as the $\mathrm{MgO}$ concentration increases, the $\mathrm{Al}_{2} \mathrm{O}_{3}$ concentration correspondingly decreases. Therefore, with our sample-alumina crucible arrangement, it was not possible to study only the effect of $\mathrm{MgO}$ on the activity coefficient of cobalt oxide in the slag, and the distribution behavior of cobalt.

\section{Summary and Conclusions}

The growing demand for rechargeable batteries will continue and increase drastically in the near future because of the rapid growth in electric transportation, mobile communication, and renewable energy storage applications. As the batteries reach end-of-life, the metal values must be returned back to supply chain via effective recycling processes. Pyrometallurgical copper smelting is one of the most attractive recycling routes for many types of scrap, including WEEE. The aim of this study is to investigate the suitability of secondary copper smelting process for recycling of battery metals lithium, cobalt, manganese, and cobalt. The experiments were conducted in alumina crucibles, at $1300{ }^{\circ} \mathrm{C}$ and in oxygen partial pressure range of $10^{-11}-10^{-8} \mathrm{~atm}$. The equilibrated samples were characterized using EPMA and LA-ICP-MS. Because of the extremely low detection limits of the latter technique, accurate values for the concentrations of $\mathrm{Li}, \mathrm{Co}, \mathrm{Mn}$, and $\mathrm{La}$ in copper alloy and slag phases were obtained, although in many analysis spots the concentrations of lithium and lanthanum in copper alloy were below the detection limits of the LA-ICP-MS. The results show that lithium, lanthanum, and manganese deported heavily in the slag, as their distribution coefficients between copper and slag were below $10^{-3.5}, 10^{-5}$, and $10^{-.5}$, respectively. For cobalt, the distribution coefficient decreased from approximately 6 to 0.1 as the oxygen partial pressure increased from $10^{-11}$ to $10^{-8}$ atm. This suggests that in extremely reducing process conditions, most cobalt can be recovered into the copper alloy, where it can be recovered in downstream process stages. However, in more oxidizing conditions, most of the cobalt deports into the slag. The addition of up to $6 \mathrm{wt} \%$ of magnesium oxide in the slag did not have a very significant effect on the behavior of any of the studied metals. However, the effect of $\mathrm{MgO}$ alone could not be isolated at spinel saturation, as the $\mathrm{Al}_{2} \mathrm{O}_{3}$ concentration in the slag decreased with increasing $\mathrm{MgO}$ concentration. For manganese and especially cobalt, the relatively high solubility in the solid primary spinel phase further reduced the yields of these metals in the copper alloy.

The distribution coefficients of lithium and lanthanum between copper alloy and slags were quantified for the first time, although they still should be regarded as upper values only. The results suggest that the pyrometallurgical secondary copper smelting process is not suitable for the recovery and recycling of lithium, lanthanum, or manganese; a pre-treatment step is required for their removal. These elements deport heavily in the slag, and it may not economically be viable to process these slags for metal recovery, as the quantities are huge. For cobalt, a noticeable fraction can be recovered in reducing process environments typical to industrial slag cleaning in nickel smelting.

Author Contributions: Conceptualization, A.D., L.K., P.T. and A.J.; data curation, A.D. and L.K.; formal analysis, A.D. and L.K.; funding acquisition, D.L. and A.J.; investigation, A.D. and L.K.; methodology, L.K. and A.J.; project administration, D.L. and A.J.; resources, M.K., D.L. and A.J.; software, L.K. and M.K.; supervision, D.L. and A.J.; validation, A.D., L.K., M.K. and P.T; visualization, A.D. and L.K.; writing-Original draft, A.D. and L.K.; writing-Review and editing, P.T., D.L., M.K. and A.J. All authors have read and agreed to the published version of the manuscript.

Funding: This work was conducted in the Business Finland-Funded SYMMET project (project no 3891/31/2018). L.K. is grateful for a doctoral study grant provided by the Finnish Steel and Metal Producer's Fund.

Acknowledgments: Lassi Pakkanen at Geological Survey of Finland conducted the EPMA analyses, and his contribution is highly appreciated. This study utilized the Academy of Finland's RawMatTERS Finland Infrastructure (RAMI), based jointly at Aalto University, GTK Espoo and VTT Espoo. 
Conflicts of Interest: The authors declare no conflict of interest. The funders had no role in the design of the study; in the collection, analyses, or interpretation of data; in the writing of the manuscript, or in the decision to publish the results.

\section{Appendix A}

Table A1. Concentration of Co, Mn, and La in metal and slag phases, based on EPMA analyses.

\begin{tabular}{|c|c|c|c|c|c|c|c|c|}
\hline \multirow{2}{*}{$\begin{array}{c}\log _{10} \\
p\left(O_{2}\right) / a t m\end{array}$} & \multirow{2}{*}{$\begin{array}{c}\text { MgO in } \\
\text { slag/wt } \%\end{array}$} & \multirow{2}{*}{ Phase } & \multicolumn{3}{|c|}{ Average Concentration/ppmw } & \multicolumn{3}{|c|}{ Standard Deviation/ppmw } \\
\hline & & & Co & Mn & La & Co & Mn & La \\
\hline \multirow{4}{*}{-8} & \multirow{4}{*}{0} & metal & 467.2 & $<\mathrm{dl}$ & $<\mathrm{dl}$ & 32.6 & - & - \\
\hline & & slag & 5741 & 9840 & 10,171 & 34.4 & 155.2 & 137.8 \\
\hline & & metal & 186.9 & $<\mathrm{dl}$ & $<\mathrm{dl}$ & 28.8 & - & - \\
\hline & & slag & 1831 & 9657 & 10,135 & 33.5 & 130.6 & 87.8 \\
\hline \multirow{4}{*}{-9} & \multirow{4}{*}{0} & metal & 1913 & $<\mathrm{dl}$ & $<\mathrm{dl}$ & 29.1 & - & - \\
\hline & & slag & 5527 & 9975 & 9850 & 58.7 & 80.2 & 187.5 \\
\hline & & metal & 1182 & $<\mathrm{dl}$ & $<\mathrm{dl}$ & 56.2 & - & - \\
\hline & & slag & 3426 & 9999 & 9903 & 73.2 & 184.2 & 307.5 \\
\hline \multirow{4}{*}{-10} & \multirow{4}{*}{0} & metal & 4786 & $<\mathrm{dl}$ & $<\mathrm{dl}$ & 101.7 & - & - \\
\hline & & slag & 3719 & 10,194 & 9982 & 41.5 & 96.5 & 190.2 \\
\hline & & metal & 1217 & $<\mathrm{dl}$ & $<\mathrm{dl}$ & 37.0 & - & - \\
\hline & & slag & 1021 & 8185 & 9438 & 39.2 & 251.2 & 285.6 \\
\hline \multirow{2}{*}{-11} & \multirow[b]{2}{*}{0} & metal & 5897 & $<\mathrm{dl}$ & $<\mathrm{dl}$ & 72.6 & - & - \\
\hline & & slag & 996.5 & 8574 & 9825 & 36.7 & 115.7 & 210.9 \\
\hline \multirow{2}{*}{$\begin{array}{c}\log _{10} \\
\mathrm{p}\left(\mathrm{O}_{2}\right) / \mathrm{atm}\end{array}$} & \multirow{2}{*}{$\begin{array}{l}\mathrm{MgO} \text { in } \\
\text { slag/wt } \%\end{array}$} & \multirow{2}{*}{ Phase } & \multicolumn{3}{|c|}{ Average Concentration/ppmw } & \multicolumn{3}{|c|}{ Standard Deviation/ppmw } \\
\hline & & & Co & Mn & La & Co & Mn & Co \\
\hline \multirow{4}{*}{-8} & \multirow{4}{*}{3} & metal & 452.7 & $<\mathrm{dl}$ & $<\mathrm{dl}$ & 22.0 & - & - \\
\hline & & slag & 5699 & 10,079 & 10,382 & 173.7 & 108.3 & 217.3 \\
\hline & & metal & 154.2 & $<\mathrm{dl}$ & $<\mathrm{dl}$ & 29.7 & - & - \\
\hline & & slag & 1349 & 10,168 & 10,487 & 34.4 & 180.2 & 76.8 \\
\hline & & metal & 1902 & $<\mathrm{dl}$ & $<\mathrm{dl}$ & 40.8 & - & - \\
\hline & & slag & 4942 & 10,163 & 10470 & 36.4 & 172.0 & 235.4 \\
\hline-9 & 3 & metal & 1200 & $<\mathrm{dl}$ & $<\mathrm{dl}$ & 22.5 & - & - \\
\hline & & slag & 3332 & 10,155 & 10,041 & 69.6 & 165.9 & 285.3 \\
\hline & & metal & 4993 & $<\mathrm{dl}$ & $<\mathrm{dl}$ & 58.1 & - & - \\
\hline & & slag & 3722 & 10,330 & 9949 & 69.4 & 79.0 & 187.0 \\
\hline-10 & 3 & metal & 628.0 & $<\mathrm{dl}$ & $<\mathrm{dl}$ & 38.0 & - & - \\
\hline & & slag & 479.5 & 9294 & 9425 & 72.3 & 231.6 & 275.8 \\
\hline & & metal & 3052 & $<\mathrm{dl}$ & $<\mathrm{dl}$ & 43.4 & - & - \\
\hline & & slag & 468.9 & 9717 & 9742 & 46.3 & 142.7 & 136.7 \\
\hline-11 & 3 & metal & 6491 & $<\mathrm{dl}$ & $<\mathrm{dl}$ & 316.3 & - & - \\
\hline & & slag & 1117 & 9677 & 9708 & 47.9 & 250.1 & 223.0 \\
\hline $\log _{10}$ & $\mathrm{MgO}$ in & Phaca & Averag & ncentra & /ppmw & Stanc & Deviati & pmw \\
\hline $\mathrm{p}\left(\mathrm{O}_{2}\right) / \mathrm{atm}$ & slag/wt\% & I nase & Co & Mn & La & Co & Mn & Co \\
\hline & & metal & 345.2 & $<\mathrm{dl}$ & $<\mathrm{dl}$ & 21.0 & - & - \\
\hline & & slag & 3185 & 10,243 & 10,757 & 49.8 & 119.9 & 129.6 \\
\hline-8 & 6 & metal & 251.4 & $<\mathrm{dl}$ & $<\mathrm{dl}$ & 47.9 & - & - \\
\hline & & slag & 2234 & 10,437 & 11,378 & 86.8 & 138.1 & 141.6 \\
\hline & & metal & 1341 & $<\mathrm{dl}$ & $<\mathrm{dl}$ & 42.2 & - & - \\
\hline & & slag & 3440 & 10,519 & 10,799 & 40.0 & 162.7 & 257.4 \\
\hline-9 & 6 & metal & 1362 & $<\mathrm{dl}$ & $<\mathrm{dl}$ & 36.3 & - & - \\
\hline & & slag & 3585 & 10,151 & 10,549 & 55.5 & 210.9 & 256.8 \\
\hline & & metal & 1515 & $<\mathrm{dl}$ & $<\mathrm{dl}$ & 54.3 & - & - \\
\hline & & slag & 1127 & 10,555 & 10,537 & 30.7 & 194.3 & 199.1 \\
\hline-10 & 6 & metal & 1983 & $<\mathrm{dl}$ & $<\mathrm{dl}$ & 49.0 & - & - \\
\hline & & slag & 1567 & 7286 & 9170 & 40.9 & 151.3 & 356.1 \\
\hline-11 & 6 & metal & 7224 & $<\mathrm{dl}$ & $<\mathrm{dl}$ & 55.3 & - & - \\
\hline-11 & 6 & slag & 1108 & 7749 & 9777 & 40.1 & 53.7 & 106.2 \\
\hline
\end{tabular}


Table A2. Concentration of Li, Mn, and La in metal and slag phases, based on LA-ICP-MS analyses.

\begin{tabular}{|c|c|c|c|c|c|c|c|}
\hline \multirow{2}{*}{$\begin{array}{c}\log _{10} \\
\mathrm{p}\left(\mathrm{O}_{2}\right) / \mathrm{atm}\end{array}$} & \multirow{2}{*}{$\begin{array}{l}\text { MgO in } \\
\text { slag/wt } \%\end{array}$} & \multirow{2}{*}{ Phase } & \multicolumn{3}{|c|}{ Average Concentration/ppm } & \multicolumn{2}{|c|}{$\begin{array}{c}\text { Standard } \\
\text { Deviation/ppm }\end{array}$} \\
\hline & & & $\mathrm{Li}$ & Mn & $\mathbf{L a} * *$ & $\mathbf{L i}^{* *}$ & Mn \\
\hline \multirow{2}{*}{-8} & \multirow{2}{*}{0} & metal & $1.31^{(1) *}$ & $2.44^{(2)}$ & $0.020^{(1)}$ & - & 1.27 \\
\hline & & slag & 10,704 & - & - & 220.10 & - \\
\hline \multirow{2}{*}{-9} & \multirow{2}{*}{0} & metal & $2.75^{(2)}$ & $1.77^{(6)}$ & $0.015^{(3)}$ & - & 0.93 \\
\hline & & slag & 10,466 & - & - & 210.24 & - \\
\hline \multirow{2}{*}{-10} & \multirow{2}{*}{0} & metal & $1.27^{(1)}$ & $2.939^{(6)}$ & $0.014^{(2)}$ & - & 0.93 \\
\hline & & slag & $10,170.67$ & - & - & 139.63 & - \\
\hline \multirow{2}{*}{-11} & \multirow{2}{*}{0} & metal & $3.74^{(2)}$ & $14.14^{(6)}$ & $0.08^{(7)}$ & - & 2.97 \\
\hline & & slag & $10,591.24$ & - & - & 153.48 & - \\
\hline \multirow{2}{*}{$\begin{array}{c}\log _{10} \\
\mathrm{p}\left(\mathrm{O}_{2}\right) / \mathrm{atm}\end{array}$} & \multirow{2}{*}{$\begin{array}{l}\text { MgO in } \\
\text { slag/wt } \%\end{array}$} & \multirow{2}{*}{ Phase } & \multicolumn{3}{|c|}{ Average Concentration/ppm } & \multicolumn{2}{|c|}{$\begin{array}{c}\text { Standard } \\
\text { Deviation/ppm }\end{array}$} \\
\hline & & & $\mathbf{L i}$ & Mn & La & $\mathbf{L i}$ & Mn \\
\hline \multirow{2}{*}{-8} & \multirow{2}{*}{3} & metal & $1.70^{(1)}$ & $0.73^{(4)}$ & $0.028^{(3)}$ & & 0.21 \\
\hline & & slag & $10,699.18$ & - & - & 274.3 & - \\
\hline \multirow{2}{*}{-9} & \multirow{2}{*}{3} & metal & $1.21^{(2)}$ & $2.56^{(7)}$ & $0.015^{(4)}$ & & 1.05 \\
\hline & & slag & $11,258.77$ & - & - & 241.4 & - \\
\hline \multirow{2}{*}{-10} & \multirow{2}{*}{3} & metal & $1.17^{(2)}$ & $3.35^{(8)}$ & $0.016^{(2)}$ & & 0.96 \\
\hline & & slag & $10,807.25$ & - & - & 257.7 & - \\
\hline \multirow{2}{*}{-11} & \multirow{2}{*}{3} & metal & $<\mathrm{dl}$ & $17.25^{(8)}$ & $0.019^{(6)}$ & - & 1.94 \\
\hline & & slag & $11,512.41$ & - & - & 185.0 & - \\
\hline \multirow{2}{*}{$\begin{array}{c}\log _{10} \\
\mathrm{p}\left(\mathrm{O}_{2}\right) / \mathrm{atm}\end{array}$} & \multirow{2}{*}{$\begin{array}{l}\text { MgO in } \\
\text { slag/wt } \%\end{array}$} & \multirow[t]{2}{*}{ Phase } & \multicolumn{3}{|c|}{ Average Concentration/ppm } & $\begin{array}{r}\text { St } \\
\text { Devia }\end{array}$ & $\begin{array}{l}\text { d } \\
\text { ppm }\end{array}$ \\
\hline & & & $\mathbf{L i}$ & Mn & La & Li & Mn \\
\hline & & metal & $4.18^{(2)}$ & $0.80^{(4)}$ & $0.022^{(3)}$ & & 0.08 \\
\hline-8 & 6 & slag & 12,035 & - & - & 209.5 & - \\
\hline & & metal & $3.43^{(4)}$ & $3.04^{(8)}$ & $0.034^{(5)}$ & & 1.13 \\
\hline-9 & 6 & slag & 10,866 & - & - & 238.9 & - \\
\hline 11 & 6 & metal & $2.85^{(4)}$ & $8.28^{(8)}$ & $0.020^{(5)}$ & & 2.11 \\
\hline-10 & 6 & slag & 12,462 & - & - & 217.1 & - \\
\hline-11 & 6 & metal & $<\mathrm{dl}$ & $10.32^{(8)}$ & $0.026^{(4)}$ & - & 2.01 \\
\hline- & 6 & slag & 11,242 & - & - & 293.9 & - \\
\hline
\end{tabular}

* The values in brackets represent concentrations (x/8) above the detection limit. ${ }^{* *}$ Lithium and lanthanum concentration in metal phase is the average value of those measurements, which were above the detection limit. For some of the samples the number of measurements above detection limit was only 1-3, therefore, the standard deviation was not calculated. 


\section{Appendix B}

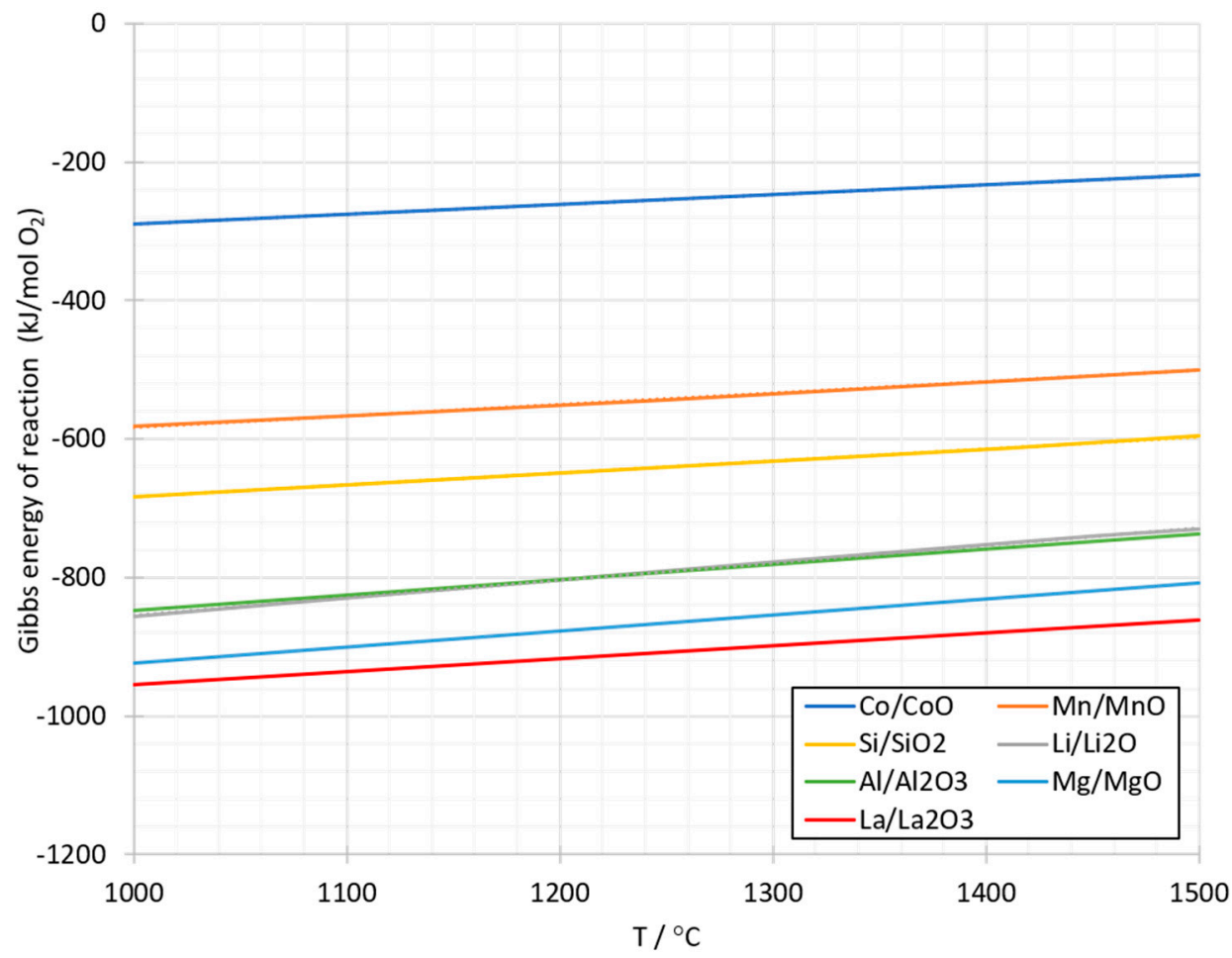

Figure A1. An Ellingham diagram for $\mathrm{Li}_{2} \mathrm{O}, \mathrm{CoO}, \mathrm{MnO}, \mathrm{La}_{2} \mathrm{O}_{3}, \mathrm{Al}_{2} \mathrm{O}_{3}, \mathrm{MgO}$, and $\mathrm{SiO}_{2}$. Calculated with HSC Chemistry 6.12.

\section{References}

1. Pinegar, H.; Smitch, Y.R. Recycling of End-of Life Lithium Ion Batteries, Part 1: Commercial Processes. J. Sustain. Met. 2019, 5, 402-416. [CrossRef]

2. Business Finland 201s9. Available online: https://www.businessfinland.fi/en/for-finnish-customers/services/ programs/batteries-from-finland/ (accessed on 21 August 2019).

3. Liu, L.; Park, J.; Lin, X.; Sastry, A.M.; Lu, W. A thermal-electrochemical model that gives spatial-dependent growth of solid electrolyte interphase in a Li-ion battery. J. Power Sources 2014, 268, 482-490. [CrossRef]

4. Lin, X.; Park, J.; Liu, L.; Lee, Y.; Sastry, A.M.; Lua, W. A Comprehensive Capacity Fade Model and Analysisfor Li-Ion Batteries. J. Electrochem. Soc. 2013, 160, A1701-A1710. [CrossRef]

5. Liu, C.; Liu, L. Optimal Design of Li-Ion Batteries through Multi-PhysicsModeling and Multi-Objective Optimization. J. Electrochem. Soc. 2017, 164, E3254-E3264. [CrossRef]

6. Espinosa, D.C.R.; Mansur, M.B. Recycling Batteries. Available online: https://doi.org/10.1016/B978-0-08102158-3.00014-8 (accessed on 28 February 2020).

7. Veloso, L.R.S.; Rodrigues, L.E.O.C.; Ferreira, D.A.; Magalhães, F.S.; Mansur, M.B. Development of a hydrometallurgical route for the recovery of zinc and manganese from spent alkaline batteries. J. Power Sources 2005, 152, 295-302. [CrossRef]

8. Al-Thyabat, S.; Nakamura, T.; Shibata, E.; Iizuka, A. Adaptation of minerals processing operations for lithium-ion (LiBs) and nickel metal hydride (NiMH) batteries recycling: Critical review. Miner. Eng. 2013, 45, 4-17. [CrossRef]

9. Sverdrup, H.U.; Ragnarsdottir, K.V.; Koca, D. An assessment of metal supply sustainability as an input to policy: Security of supply extraction rates, stocks-in-use, recycling, and risk of scarcity. J Clean. Prod. 2017, 140, 359-372. [CrossRef]

10. Shedd, K. Mineral Commodity Summaries of Cobalt. U.S. Geological Survey. 2019. Available online: https://prd-wret.s3-us-west-2.amazonaws.com/assets/palladium/production/s3fs-public/ atoms/files/mcs-2019-cobal_0.pdf (accessed on 21 August 2019). 
11. Zhang, S.; Ding, Y.; Liu, B.; Chang, C. Supply and demand of some critical metals and present status of their recycling in WEEE. Waste Manag. 2017, 65, 113-127. [CrossRef]

12. Shedd, K. Mineral Commodity Summaries of Lithium. U.S. Geological Survey. 2019. Available online: https://prd-wret.s3-us-west-2.amazonaws.com/assets/palladium/production/atoms/files/ mcs-2019-lithi.pdf (accessed on 21 August 2019).

13. Martin, G.; Rentsch, L.; Höck, M.; Bertau, M. Lithium market research —Global supply, future demand and price development. Energy Storage Mater. 2017, 6, 171-179. [CrossRef]

14. Reck, B.K.; Graedel, T.E. Challenges in metal recycling. Science 2012, 337, 690-695. [CrossRef]

15. Helbig, C.; Bradshaw, A.M.; Wietschel, L.; Thorenz, A.; Tuma, A. Supply risks associated with lithium-ion battery materials. J. Clean. Prod. 2017, 172, 274-286. [CrossRef]

16. Shuva, M.A.H.; Rhamdhani, M.A.; Brooks, G.A.; Masood, S.; Reuter, M.A. Thermodynamics data of valuable elements relevant to e-waste processing through primary and secondary copper production: A review. J. Clean. Prod. 2016, 131, 795-809. [CrossRef]

17. EU Report on Critical Raw Materials and the Circular Economy 2018. Commission Staff Working Document. Available online: http://ec.europa.eu/docsroom/documents/27348 (accessed on 12 June 2018).

18. Bernardes, A.M.; Espinosa, D.C.R.; Tenório, J.A.S. Recycling of batteries: A review of current processes and technologies. J. Power Sources 2004, 130, 291-298. [CrossRef]

19. Ordoñez, J.; Gago, E.J.; Girard, A. Processes and technologies for the recycling and recovery of spent lithium-ion batteries. Renew. Sustain. Energy Rev. 2016, 60, 195-205. [CrossRef]

20. Zheng, X.; Zhu, Z.; Lin, X.; Zhang, Y.; He, Y.; Cao, H.; Sun, Z. A Mini-Review on Metal Recycling from Spent Lithium Ion Batteries. Engineering 2018, 4, 361-370. [CrossRef]

21. Cheret, D.; Santen, S. Battery Recycling. U.S. Patent 7,169,206 B2, 30 January 2007.

22. Tirronen, T.; Sukhomlinov, D.; O’Brien, H.; Taskinen, P.; Lundström, M. Distributions of lithium-ion and nickel-metal hydride battery elements in copper converting. J. Clean. Prod. 2017, 168, 399-409. [CrossRef]

23. Kim, H.G.; Sohn, H.Y. Effects of $\mathrm{CaO}, \mathrm{Al}_{2} \mathrm{O}_{3}$, and $\mathrm{MgO}$ additions on the copper solubility, ferric/ferrous ratio, and minor-element behavior of iron-silicate slags. Metall. Mater. Trans. B 1998, 29, 583-590. [CrossRef]

24. Takeda, Y.; Ishiwata, S.; Yazawa, A. Distribution equilibria of minor elements between liquid copper and calcium ferrite slag. Trans. Jpn. Inst. Met. 1983, 24, 518-528. [CrossRef]

25. Liu, X.; Grimsey, E.J. The effect of silica, alumina, calcia and magnesia on the activity coefficient of cobalt oxide in iron silicate slags. In Proceedings of the 5th International Conference on Molten Slags, Fluxes and Salts '97, Sydney, Australia, 5-8 January 1997; pp. 709-718.

26. Jung, S.M.; Kim, S.H.; Rhee, C.H.; Min, D.J. Thermodynamic Containing FeO Study on MnO Behavior in MgO-saturated Slag. ISIJ Int. 1993, 33, 1049-1054. [CrossRef]

27. Eom, C.H.; Lee, S.H.; Park, J.G.; Park, J.H.; Min, D.J. Thermodynamic Behavior of Manganese Oxide in Lime-based Manganese Smelting Slags. ISIJ Int. 2015, 56, 37-43. [CrossRef]

28. Haccuria, E.; Hayes, P.C.; Jak, E. Phase equilibria studies of the " $\mathrm{MnO}^{\prime \prime}-\mathrm{Al}_{2} \mathrm{O}_{3}-\mathrm{SiO}_{2}$ system in equilibrium with metallic alloy. Part 1: Development of the technique and determination of liquidus isotherms between 1 $423 \mathrm{~K}$ and $1523 \mathrm{~K}$. Int. J. Mater. Res. 2014, 105, 941-952. [CrossRef]

29. Haccuria, E.; Hayes, P.C.; Jak, E. Phase equilibria studies of the " $\mathrm{MnO}^{\prime}-\mathrm{Al}_{2} \mathrm{O}_{3}-\mathrm{SiO}_{2}$ system in equilibrium with metallic alloy. Part 2: Phase equilibria. Int. J. Mater. Res. 2015, 106, 225-236. [CrossRef]

30. Guoxing, R.; Songwen, X.; Meiqiu, X.; Bing, P.; Youqi, F.; Fenggang, W.; Xing, X. Recovery of valuable metals from spent lithium-ion batteries by smelting reduction process based on $\mathrm{MnO}-\mathrm{SiO}_{2}-\mathrm{Al}_{2} \mathrm{O}_{3}$ slag system. In Advances in Molten Slags, Fluxes, and Salts: Proceedings of the 10th International Conference on Molten Slags, Fluxes and Salts (MOLTEN16); Reddy, R.G., Chaubal, P., Pistorius, P.C., Pal, U., Eds.; TMS (The Minerals, Metals \& Materials Society): Pittsburgh, PA, USA, 2016.

31. Sukhomlinov, D.; Klemettinen, L.; Avarmaa, K.; O’Brien, H.; Taskinen, P.; Jokilaakso, A. Distribution of $\mathrm{Ni}, \mathrm{Co}$, Precious, and Platinum Group Metals in Copper Making Process. Metall. Mater. Trans. B 2019, 50, 1752-1765. [CrossRef]

32. Sun, T.; Kennedy, M.W.; Yurramendi, L.; Aldana, J.L.; Del Rio, C.; Arnout, S.; Tranell, G.; Aune, R.E. Pyrometallurgical Treatment of Apatite Concentrate with the Objective of Rare Earth Element Extraction: Part I. J. Sustain. Metall. 2017, 3, 829-845. [CrossRef]

33. Borra, C.R.; Blanpain, B.; Pontikes, Y.; Binnemans, K.; Van Gerven, T. Smelting of Bauxite Residue (Red Mud) in View of Iron and Selective Rare Earths Recovery. J. Sustain. Metall. 2016, 2, 28-37. [CrossRef] 
34. Klemettinen, L.; Aromaa, R.; Dańczak, A.; O’Brien, H.; Taskinen, P.; Jokilaakso, A. Distribution Kinetics of Rare Earth Elements in Copper Smelting. Sustainability 2020, 12, 208. [CrossRef]

35. Piskunen, P.; Avarmaa, K.; O’Bren, H.; Klemettinen, L.; Johto, H.; Taskinen, P. Precious Metal Distributions in Direct Nickel Matte Smelting with Low-Cu Mattes. Metall. Mater. Trans. B 2017, 49, 98-112. [CrossRef]

36. Klemettinen, L.; Avarmaa, K.; Taskinen, P. Slag Chemistry of High-Alumina Iron Silicate Slags at $1300{ }^{\circ} \mathrm{C}$ in WEEE Smelting. J. Sustain. Metall. 2017, 3, 772-781. [CrossRef]

37. Klemettinen, L.; Avarmaa, K.; O’Brien, H.; Taskinen, P.; Jokilaakso, A. Behavior of Tin and Antimony in Secondary Copper Smelting Process. Minerals 2019, 9, 39. [CrossRef]

38. Davies, R.H.; Dinsdale, A.T.; Gisby, J.A.; Robinson, J.A.J.; Martin, S.M. MTDATA—Thermodynamics and Phase Equilibrium Software from the National Physical Laboratory. CALPHAD 2002, 26, 229-271. [CrossRef]

39. Bastin, G.F.; Heijligers, H.J.M. Quantitative Electron Probe Microanalysis of Ultralight Elements (Boron-Oxygen). Scanning 1990, 12, 225-236. [CrossRef]

40. Pouchou, J.L.; Pichoir, F. Basic expression of "PAP" computation for quantitative EPMA. In Proceedings of the 11th International Congress on X-ray Optics and Microanalysis (ICXOM), London, ON, Canada, 4-8 August 1986; Brown, J.D., Packwood, R.H., Eds.; University of Western Ontario: London, ON, Canada, 1986; pp. 249-256.

41. UQAC Pressed Sulphide Pellet Reference Material. Available online: https://sulfideslasericpms.wordpress. com/rm-available/ (accessed on 21 August 2019).

42. Wilson, S.A.; Ridley, W.I.; Koenig, A.E. Development of sulfide calibration standards for the laser ablation inductively-coupled plasma mass spectrometry technique. J. Anal. Atom. Spectrom. 2002, 17, 406-409. [CrossRef]

43. Jochum, K.P.; Weis, U.; Stoll, B.; Kuzmin, D.; Yang, Q.; Raczek, I.; Jacob, D.E.; Stracke, A.; Birbaum, K.; Frick, D.A.; et al. Determination of Reference Values for NIST SRM 610-617 Glasses Following ISO Guidelines. Geostand. Geoanal. Res. 2011, 35, 397-429. [CrossRef]

44. Avarmaa, K.; Yliaho, S.; Taskinen, P. Recoveries of rare elements Ga, Ge, in and Sn from waste electric and electronic equipment through secondary copper smelting. Waste Manag. 2018, 71, 400-410. [CrossRef] [PubMed]

(C) 2020 by the authors. Licensee MDPI, Basel, Switzerland. This article is an open access article distributed under the terms and conditions of the Creative Commons Attribution (CC BY) license (http://creativecommons.org/licenses/by/4.0/). 